\title{
correspondence
}

\section{The fate of the Taj Mahal}

SIR,-M. K. Agarwal has made a plea (2 November, page 10) that India should go ahead with the construction of the proposed oil refinery near the Taj Mahal and asks whether a poor nation can afford the luxury of keeping its monuments in their pristine beauty while it cannot provide a minimum for its people. While the intentions are laudable, I would like to contest the rationale.

If the shifting of the proposed site of the refinery by a few hundred miles is really going to affect the economic development of India to a significant degree, $\mathrm{Mr}$ Agarwal might indeed have a case. If there are scores of other marble monuments across the country which are all threatened by projects vital to reduce human misery, he may again be justified in criticising the efforts to save the Taj Mahal from corrosion, as one cannot go around cancelling all development schemes.

While changing the site of the refinery will only cause a bit of a headache for the planners and the bureaucrats, $I$ cannot see much harm even in completely dropping the proposal. Looking through India's record since independence, no sincere observer can escape the fact that despite her impressive technological progress, the percentage of the population under the starvation line has remained around $60 \%$. In absolute numbers, poverty has only increased.

The massive nuclear reactors, steel factories, refineries and the rest have benefited mostly the affluent and the urban middle-class. The majority of poor rural India, which should be the primary concern of any development project, has hardly gained from the industrial growth. In fact a case can be made that this western style technological progress has done more harm directly by increasing the stranglehold of the big industrialists, and indirectly by diverting valuable money from investment in the rural sector and in appropriate,

labour-intensive, small scale technology.

One could also argue that without fundamental social changes and agrarian reforms, any industrial progress in India can only be harmful.

Rather than being an economic liability, the Taj Mahal has always brought enormous foreign exchange to India. No tourist leaves the country without visiting Agra. Even

commercially, it would be wiser to back the Taj Mahal rather than the refinery. Under these circumstances, the effort to save it from corrosion is hardly a luxury for a poor country.

If the construction of the oil installation goes ahead and the pollution does damage the monument irreparably, posterity will never condone this generation for sacrificing one of mankind's great architectural wonders for a very dubious (perhaps despicable) economic reason.

T. R. VIDYASAGAR

UMIST,

Manchester, UK

\section{Discussing values and judgments}

SiR,--I was most interested in your editorial comments of 20 July and feel constrained to address some of the inconsistencies they contain. In the first place, the separation of scientists from "the others" in terms of their ability to discuss values and human judgments and to deal with "convergent" rather than "divergent" problems seems to be both misleading and patently false.

During my years at university, I was constantly made aware of the barriers erected between the arts and sciences and was frequently told that "you are unable to understand these issues because your scientific training hasn't given you the necessary foundations for understanding general cultural and value systems." Rubbish! What I have observed during my years in university and subsequently is that non-scientifically trained graduates tend, if anything, to be a bit more dogmatic in their beliefs than scientists and are often unable to carry on philosophical discussions in a logical and consistent manner.

My education prepared me to make value judgments and the scientific method has fitted me admirably to address open-ended problems in a reasonable way.

All of your analysis seems to address reaction to recent evaluations of the Windscale inquiry and, specifically, the remarks of Professor David Pearce. You make further reference to the fact that the nuclear industry appears unwilling to discuss values-including the fear of nuclear weapons proliferation. Having chosen to "leave" such speculation (with which term you correctly indentified your ramblings), I should like to judge on its own merit your recommendation that school children be politically educated by requiring study projects linked with technological issues, such as the need for fast breeder reactors. In this way, you suggest, the humanist and the scientist (again, this false separation of the two aspects of each of us) can learn from one another. Assuming that you are referring to pre-university education, I very much doubt that your desired goals will be reached, since it is unlikely that such students are well enough prepared for the kind of in-depth study required to achieve these ends.

I should like to make further comment concerning the remarks of David Pearce in the following discussion of the values which are at the root of the nuclear debate. His statement proposing that opposition to nuclear power derives from differences in value systems strikes at the heart of this controversy; however, as I read them, his comments suggest that the "image of infinite credibility" is a cloak worn only by the nuclear industry and that they, so deceiving themselves, stand in the way of clear discussion of the values which lie beneath the issues discussed at Windscale. In a way this is rather humorous for, from my position on the other side of the controversy from that taken by David Pearce, it appears that this cloak is being worn by opponents of nuclear power development. I was glad to see him admit that there were many "men of reason" characterising the pro-nuclear stance but the impression given in his article was that this was the exception rather than the rule. With this same proviso, I could change the term 'industry' into the term 'environmentalist' and make the entire article read very much to my likingperhaps proving, as Pearce suggests, that the debate has fallen to a very low level indeed.

A clue to the problem (which is raised by discussions such as the one presented by Pearce) is revealed when one considers the 'problem' of defining public accountability for decisions made in a social context. Institutions must be modified to accommodate other points of view, states Pearce, with the thinly-veiled threat that failure to do so will result in conflict (presumably including physical violence). I suggest that the real problem in the nuclear debate is the fact that institutions have been modified to the point where everyone, no matter where his expertise lies, presumes himself fully-qualified to speak on every issue and, for this reason, totally irrational points of view are given prominence simply because of their sensational value in the public eye.

Heaven help our society if orderly inquiry into questions such as that recently carried out at Windscale is replaced by mob rule because people such as David Pearce are unprepared to accept defeat when their values are weighed in duly-constituted public inquiry and rejected. Justice Parkers' report seemed a well-reasoned and impartial survey of the many questions brought up at the inquiry and the fact that he dismissed out of hand a number of alternative value systems proposed by some of the intervenors is not a result of his failure to understand but simply a judgment based on his understanding of the will of the people of Great Britain as expressed through past legal decisions and acts passed by their elected representatives in Parliament.

Kingsport, TN, USA

$$
\text { R. C. FORRESTER III }
$$

\section{Food production has kept up}

SiR,-I was disappointed to see in your pages (26 October, page 698) the myth that there has lately been an "inexorable increase in the world's population without a commensurate increase in food supplies". FAO data show that during the past two decades of rapid population growth, while population has grown at $2 \%$ per annum food production has grown by an average $2.8 \%$ per annum. These results have been discussed in detail in World Futures (C. Freeman and M. Jahoda (eds), Martin Robertson, London; 1978).

University of Sussex,

JoHN GribBin 